Research Article

https://doi.org/10.22455/2541-7894-2021-11-155-182

UDC 821.111
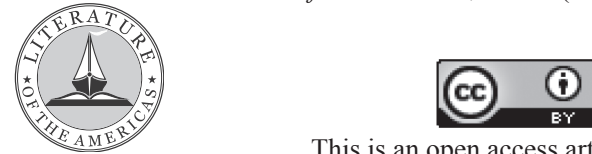

This is an open access article distributed under the Creative

Commons Attribution 4.0

International (CC BY 4.0)

\title{
Michael BOWDEN
}

\section{SHAMELESSNESS AND NEW SINCERITY: DOSTOEVSKY, DAVID FOSTER WALLACE, AND TRUMP'S AMERICA}

Abstract: The ascendency of Donald Trump to President of the United States was marked by the concretisation of the "post-truth" era, an era in which brazen falsehoods not only withstood counterclaims to veracity but seemed to derive their legitimacy from their opposition to readily accepted truths. Epitomised by Kellyanne Conway's infamous promulgation of "alternative facts," the defining characteristic of post-truth politics seemed to be that the content of an utterance mattered less than the shamelessness with which it was uttered. It evidenced a divorce between traditional concepts of sincerity and the truth on which such sincerity was traditionally premised, allowing for the post-truth manipulation of shamelessness to make the most forceful claim over the sincere. This trend, I will argue in this essay, has its roots in the abundance of cynicism that beset American postmodernism, which along with post-truth shamelessness also gave rise to the cultural need for a new understanding of sincerity. I intend to trace how Fyodor Dostoevsky's work influenced one of the foremost proponents of such new sincerity, the novelist David Foster Wallace. Giving particular focus to Dostoevsky's emphasis on shame in his post-Siberian works, especially in the portrayal of Fyodor Karamazov, I will argue that such emphasis has its correspondence in Emmanuel Levinas's theorisation of the ethical. I will conclude by suggesting that Levinasian ethics, which represent a departure from the totalising tendency of Enlightenment philosophy, might thereby serve as the basis for a new type of sincerity, one that maintains a sense of the ethical in the face of post-truth shamelessness.

Keywords: Fyodor Dostoevsky, David Foster Wallace, Donald Trump, shamelessness, New Sincerity, Emmanuel Levinas, ethics.

Information about the author: Michael Bowden, $\mathrm{PhD}$ student, The University of Leeds, Woodhouse Lane, Leeds LS2 9JT, United Kingdom. ORCID ID: https://orcid.org/0000-00032903-5007. E-mail: mjbowden8789@gmail.com.

For citation: Bowden, Michael. "Shamelessness and New Sincerity: Dostoevsky, David Foster Wallace, and Trump's America." Literature of the Americas, no. 11 (2021): 155-182. https://doi.org/10.22455/2541-7894-2021-11-155-182. 
Научная статья

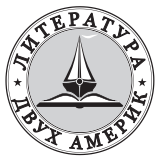

https://doi.org/10.22455/2541-7894-2021-11-155-182

УДК 821.111

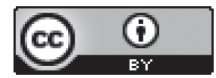

This is an open access article distributed under the Creative

Commons Attribution 4.0 International (CC BY 4.0)

\section{Майкл БОУДЕН}

\section{БЕССТЫДСТВО И НОВАЯ ИСКРЕННОСТЬ: ДОСТОЕВСКИЙ, ДЭВИД ФОСТЕР УОЛЛЕС И АМЕРИКА ТРАМПА}

Аннотация: Избрание Дональда Трампа президентом Соединенных Штатов ознаменовалось ускоренным наступлением эпохи «постправды», когда наглая ложь не только успешно претендовала на статус правды, но и, казалось, самоутверждалась за счет противостояния общеизвестным истинам. Определяющая характеристика политики постправды, квинтэссенцией которой стала скандальная пропаганда Келлиэнн Конуэй «альтернативных фактов», заключалась, пожалуй, в том, что значение имело не столько содержание высказывания, сколько бесстыдство, с каким его озвучивали. Между традиционными понятиями искренности и правды, лежащей, как принято было считать, в основе такой искренности, возник разрыв, поэтому откровенно бесстыдным заявлениям в духе постправды удавалось убедительно доказывать свою искренность. Основной тезис статьи состоит в том, что данная тенденция восходит к преизбытку цинизма в американском постмодернизме, наряду с бесстыдством постправды породившего в культуре потребность в новом понимании искренности. Автор показывает, как творчество Ф.М. Достоевского повлияло на одного из наиболее заметных представителей «новой искренности» - романиста Дэвида Фостера Уоллеса. Учитывая, какую важную роль играет стыд в произведениях Достоевского, написанных после возвращения из сибирской ссылки (особенно важен здесь для нас образ Федора Карамазова), представляется необходимым проследить, как такая расстановка акцентов соотносится с осмыслением этического в трудах Эммануэля Левинаса. Наконец, в статье высказывается предположение, что этика Левинаса, отвергающая тягу философии эпохи Просвещения к обобщениям, могла бы послужить фундаментом для нового типа искренности - сохраняющего представление о морали перед лицом бесстыдства постправды.

Ключевые слова: Ф.М. Достоевский, Дэвид Фостер Уоллес, Дональд Трамп, бесстыдство, «новая искренность», Эммануэль Левинас, этика

Информация об авторе: Майкл Боуден, аспирант, Университет Лидса, Вудхаус Лейн, LS2 9JT г. Лидс, Великобритания. ORCID ID: https://orcid.org/0000-0003-2903-5007. E-mail: mjbowden8789@gmail.com.

Для цитирования: Боуден М. Бесстыдство и новая искренность: Достоевский, Дэвид Фостер Уоллес и Америка Трампа // Литература двух Америк. 2021. № 11. С. 155-182. https://doi.org/10.22455/2541-7894-2021-11-155-182. 
On November 3, 2020, as I began preliminary note-making and literature reviews to develop the ideas that would form the present article, in the background of my living room my muted television displayed the initial results of the $59^{\text {th }}$ quadrennial US Presidential election. Several days later, amidst premature declarations of victory and baseless accusations of electoral fraud from the Republican campaign and its supporters, the Associated Press and most major television networks affirmed Joe Biden as the victor. It was an affirmation that was meant to mark the culmination of a presidency that "sent shockwaves through the US political system," to signify the potential cessation of the "bewildering [...] drama, discord and daily shifts" of fortune that inundated Donald Trump's presidency [Schaefer 2021: 109-110]. In the weeks that followed, Trump's refusal to concede defeat and public incitement to violence engendered the Capitol riot of January 6, 2021. It was a sobering reminder of the fractured nature and subterranean violence of US politics, which serve as a metonym for the traditionally (albeit reductively) named "Western" democracies.

Turning to the past to aid in understanding a "bewildering" present is a commonly accepted practice; indeed, Todd Schaefer's use of Richard Neustadt's 1960 model for analysing presidential decision-making is itself an example of this practice. And, with regards to the topic of this essay, I am not the first to read something Dostoevskian in Trump's rhetoric, or the ideology he emblematises. Of note is Ani Kokobobo's article for The Conversation at the height of Trump's 2016 election campaign, and her 2020 follow-up piece in Salon. In both, Kokobobo relates Trump's "riotous rhetoric and steady stream of scandals" with the narrative interplay between Stavrogin, Pyotr Verkhovensky and the political nihilists of Demons [Kokobobo 2016]. Regardless of the inverted political leanings of 1860s Russian nihilism and Trump's own brand of American Republicanism, Kokobobo parallels the similar "anti-intellectual and impulse-driven nature" of both movements [Kokobobo 2016]. Support for both Verkhovensky and Trump is "primarily emotion-based," despite neither figure offering much by way of "concrete political plans" beyond their "notable anti-establishment sentiments" [Kokobobo 2016]. Instead, claims Kokobobo, Verkhovensky/Trump supporters "feel empowered" by their analogous "deep-seated irreverence" for convention, and are drawn "to the spectacle of [...] the gossip and scandals" they respectively create [Kokobobo 2016].

This essay looks to extend Kokobobo's observations, moving beyond her comparison of the "devastating nihilism that consumes society" 
in $19^{\text {th }}$-century Russia and the present-day U.S. [Kokobobo 2021]. It will seek instead to assess one potential reason for the resurgence of the political appeal of scandalous spectacles by contrasting the contemporary American socio-cultural climate with the entreaty for a new sincerity made by the author David Foster Wallace, among others. ${ }^{1}$ Wallace, whose work was heavily influenced by Dostoevsky, was a prominent critic of the "congenital skeptcism" of American art and literature from mid-1980s onwards [Wallace 2014: 272]. ${ }^{2}$ He claimed, in his fiction, interviews and journalistic essays, that such scepticism was the legacy of the way the irony and cynicism of early postmodern American art had been co-opted by the commercial interests of the digital age, particularly televisual advertising. The result was a type of fiction, as Wallace said of his literary contemporaries, that was "thematically shallow and lightweight," even "morally impoverished" [Wallace 2014: 273]. In the words of the Wallace scholar Adam Kelly, by styling his fiction as antagonistic to the sceptical legacy of postmodernism Wallace "affirmed and embodied sincerity as a crucial value in his life and work, perhaps even as that work's defining feature" [Kelly 2010: 131].

Yet Wallace was likewise attuned to the difficulty of simply reincorporating sincerity back into daily American life and art. The effect of postmodernism (and its theoretical counterpart, poststructuralism), as Wallace read it, was to engender an in-built cultural disavowal of what he terms "single-entendre principles," the centralised artistic concern for traditionally unifying notions such as love, faith and duty, as well as their anchoring metaphysical universals like God and Truth [Wallace 1998: 81]. Because the concept of a univocal truth is integral to the assertion of sincerity, Wallace

A distinction must be made here between the complex portrayal of sincerity in Wallace's writings and New Sincerity, the somewhat uncodified cultural and theoretical movement that seeks new engagements with sincerity in the wake of postmodern cynicism and irony. Whilst Wallace, as this essay will show, cannot be separated from New Sincerity as a movement, his exact relationship with it is as yet undefined academically (primarily because there is no set definition of what precisely constitutes New Sincerity). With that in mind, I have chosen to term Wallace's engagement with postmodern sincerity "new sincerity" (i.e., in the lowercase), in order to avoid the easy association between Wallace and the so-called New Sincerity movement. References in this essay to "New Sincerity" are reserved for scholars (such as Kelly and Colton, discussed below) who do identify Wallace with the New Sincerity movement. For one of the foremost interrogations of sincerity after postmodernism, see the collection of essays in [Alphen, Bal, Smith 2008].

2 Wallace's review of Frank's The Miraculous Years, which develops into an extended meditation on Dostoevsky's own art, is the starting point for an assessment of Dostoevsky's influence over him. For an analysis on the intertextuality between Dostoevsky and Wallace, see [Jacobs 2007]. 
recognised that authors seeking to return sincerity to fiction would already "be outdated, of course, before they even started. Dead on the page. Too sincere [...]. Backward, quaint, naïve, anachronistic" [Wallace 1998: 81]. This was the "novelty" of Wallace's return to sincerity: the new sincerity had to negotiate the desire to progress beyond the congenital scepticism and moral impoverishment of the age, and a now-quixotic attachment to singular truth.

The contrast between Wallace's new sincerity and Trump's ascendency is thus illuminating. The premise of this essay is that new sincerity and Trump's political manipulation of scandal, and especially of shamelessness, are opposing responses to the same condition: the congenital scepticism of the postmodern American condition. Whilst new sincerity must wrestle with itself as an incongruous condition, Trump's shameless rhetoric manages to position itself exterior to traditional notions of truth and sincerity, yet simultaneously maintains the overriding structure of truth's relation to power. In fact, scandal and shamelessness fashion themselves as the final remnants of singular truth precisely because they oppose traditional notions of truth and power: instead of a univocal authority that imparts truth in exchange for ideological subjugation, Trump's political shamelessness occupies the territory of sincere truth through its very antagonism to univocal authority. Traditional sincerity may no longer be trustworthy, but Trump's shamelessness inspires the trust of his supporters because it feigns a sincere hostility to tradition.

As mentioned above with reference to Kokobobo's articles, Trump's adoption of shamelessness and scandal has many Dostoevskian prototypes; to Kokobobo's list can be added The Idiot's General Ivolgin and Lebedev, and Captain Lebyadkin in Demons. My focus, however, will be on Fyodor Karamazov, who is claimed by Deborah Martinsen's study of shame in Dostoevsky as the foremost of Dostoevsky's shameless figures [Martinsen 2003]. Martinsen's work, however, argues that Dostoevsky's use of the dynamics of shame is a decisive component of his novelistic ethical strategy. In particular, the exposure to shamelessness disorients characters and readers alike, to the extent that it reveals their unwitting complicity in a shameful status quo. My aim, therefore, is to draw a connection between Wallace's new sincerity and Dostoevsky's strategies of shame. The essay will search for a foundation for the "morally passionate, passionately moral" in both life and art that need not resort to the anachronism of traditional notions of authoritative truth, as emblematised by the Elder Zosima [Wallace 2014: 274]. Understanding Dostoevsky's ethical influence over Wallace thus means finding a way to read Zosima's counselling of Fyodor in secular terms. I will conclude by 
gesturing towards the ethical implications of Dostoevskian polyphony, as theorised by Mikhail Bakhtin. These implications, I will argue, allow for an interpretation of shame and shamelessness that accords with the ethical philosophy of Emmanuel Levinas, pertinently aligning with Levinas's adoption of Zosima's maxim "each of us is guilty in everything before everyone, and I most of all" as an adage for his theory of illimitable responsibility [Dostoevsky 2004: 289]. ${ }^{3}$

\section{II}

Sincerity, wrote the scholar Aaron Colton in the months before Trump's election victory, is the "common element" between Trump's "rage-fueled, speak-my-mind attitude" and a certain strand of American art and literature from the late- $20^{\text {th }}$ and early $21^{\text {st }}$-century [Colton 2016]. Colton's hypothesis mirrors the one put forward by this essay: the renewed significance of sincerity in American art is a response to the same cultural conditions that allowed for Trump's political success. Colton argues that the New Sincerity movement, which he associates not only with Wallace but with the "vulnerability of Bright Eyes and Cat Power" and the "homemade aesthetic of Wes Anderson," sought to reenergise "an apathetic youth culture" and correct "the pageantry, experimentalism, and detachment of the 1980s." His essay, however, portrays Trump's success as a warning against "sincerity's darker consequences" [Colton 2016]. Noting how Trump's alleged authenticity masquerades for his political nihilism, Colton perceives this form of political "sincerity" as "an antidote to the 'political correctness' of democrats, pundits, and liberal arts majors alike." He compares sincerity's emphasis on being "true" to one's own self with "good old Republican accountability," the proverbial "pulling yourself up by your own bootstraps" [Colton 2016]. Such simple-minded accountability can only thrive through claiming to cure the "American government of its characteristic dishonesty." Trump, writes Colton, garners appeal solely through representing "a politics in which candidates say only what they mean," suggesting that the content of what is actually said is unimportant as long as it stands for sincerity in opposition to a conspicuously insincere political tradition [Colton 2016]. In this way, having "sniffed out the cultural obsession with sincerity," Trump is able to "ingeniously" transpose it to "populist fearmongering." Presumably, the prejudicial attitudes that Trump arouses in

3 The expression is first formulated by Zosima's brother Markel. According to Jill Robbins, the phrase (and its variations) "occurs nearly a dozen times in Levinas's work" [Robbins 1999: 147]. 
his support base are spoken, chanted and tweeted with some form of sincerity, a "being true" to the animosity shaped by centuries of social hegemony and re-legitimised by Trump's populism. In this way, Colton dismisses sincerity as holding "no moral guarantee" [Colton 2016].

Yet the fundamental flaw of Colton's whole argument is his conflation of sincerity, as it is traditionally understood, and the so-called New Sincerity movement, particularly as it can be identified in Wallace's writings. Traditional sincerity is contingent upon an abstracted ideal of a singular truth, stemming from the Platonic and Aristotelian influences over European Renaissance and Enlightenment philosophy. Indeed, Lionel Trilling's seminal study of sincerity and authenticity begins by locating sincerity's origins in Early Modern Europe, citing Polonius's exhortation "to thine own self be true" as an emblem of the introduction of sincerity to the "moral life of Europe" [Trilling 1980: 4-5]. Colton in this way exposes his own conflation of sincerity and new sincerity when he notes the latter's resemblance to Republican accountability: traditional sincerity and modern republicanism naturally resemble each other because both are rooted in Enlightenment thought. ${ }^{4}$ Sincerity in this regard would carry a moral guarantee aligned with the principles of the Enlightenment, the essential "true self" that finds its place within the dictates of singular ideals such as "Reason" and "Liberty." The certainty of such principles, however, were the primary targets of a critical tradition that came to prominence during European modernism and reached its apotheosis in poststructural theory and postmodern art. From Braque to Baudrillard, the certainty of either a true self or the universal applicability of "Reason" has been driven to near extinction.

New sincerity follows in the wake of postmodern/poststructural thought, seeking neither to ignore nor reject its critical legacy, and so cannot be confused with traditional sincerity's philosophical origins. As Luke Turner, creator of a manifesto for the "metamodern" movement which shares many ideological affinities with new sincerity, writes, "postmodern irony and cynicism is the default setting" for "a generation raised in the " $80 \mathrm{~s}$ and '90s" [Turner 2015]. A return to the singular truth of traditional sincerity is naively anachronistic at best and impossible at worst. "However," Turner continues, "despite, or rather because of this, a yearning for meaning-for sincere and constructive progression and expression - has come to shape today's dominant cultural mode" [Turner 2015]. New sincerity, like meta-

4 For more on how European Enlightenment philosophy influenced the formation of the American republic, see [Ferguson 1997]. 
modernism, strives to negotiate the resurgence of sincerity within a culture saturated by postmodern cynicism. Rather than encapsulating the absence of moral guarantees, it seeks an alternative to the moral guarantee provided by traditional sincerity, the absence of which both predates and motivates it. ${ }^{5}$

Accordingly, associating Trump's politics with sincerity is likewise fraught with complications. Whilst it can never be known whether the sentiments he provokes in his supporters under the banner of anti-authoritarianism (xenophobia, misogyny, ableism, etc.) are sincere, in the sense that those supporters "truly" mean them, Trump's own strategy is a product of and dependent on the same postmodern cynicism that inspires new sincerity. His presidential tenure is indissociable with the so-called "post-truth" political era; though the phrase precedes Trump, his especial use of the modern world's abundance of media platforms to exploit "the obfuscation of facts, abandonment of evidential standards in reasoning, and outright lying" in part prompted Oxford Dictionaries to name "post-truth" its 2016 term of the year [McIntyre 2018: 1]. ${ }^{6}$ Cynicism towards a singular ideological truth necessarily lays the foundations for the emergence of post-truth politics: without the authoritative demarcation of the true narrative from false ones, any claim to veracity can be treated as legitimate, even ones directly contradicting other established claims. This ultimately engenders a situation in which it is left to each individual recipient of multiple and contradictory "truths" to actively decide which one to believe in, to determine which one is sincere. Post-truth sincerity is multiform and competitive.

More pertinent to Trump's tactical use of shamelessness is post-truth's affiliated phrase "alternative facts," infamously used in 2017 by his former Senior Counselor, Kellyanne Conway. The concept of an alternative fact is crucial to the way shamelessness is manipulated to stand for sincerity in a post-truth age. In his essay on New Sincerity in Wallace, Kelly makes an aside on "conditional secrecy" as understood by Jacques Derrida in The Gift of Death. For Kelly (reading Derrida), the "conditional secret, describable in terms of unveiling, within the logic of surface and depth, is about power power lies in knowledge of the secret and the ability to uncover the truth it hides." Most forms of narrative, argues Kelly, just like "most political discourse, is structured by this kind of conditional secrecy" [Kelly 2010: 143]. Like an author that induces readers with the promise of narrative coherence,

5 For more on the resemblance of the New Sincerity movement and metamodernism, see [Akker, Gibbons, Vermeulen 2017: 1-20].

6 McIntyre's work opens with an etymology of "post-truth" and an analysis of its recent correlation with Trump and the 2016 Brexit campaign. 
an ideological authority offers its adherents initiation into "the secret" (i.e., religious/juridical/ethical truth) on the condition that those adherents submit to its dictates (worship/legality/ethical practice). Conditional secrecy is thus dependent on the authority of a singular truth. That truth is unveiled to those who are subjugated. In a post-truth era, conditional secrecy loses its force. If the validity of that secret's "truth" is questionable, the authority of its unveiler is diminished.

The theory of conditional secrecy is useful because it reveals how shame operates within the context of traditional notions of truth and sincerity. Balanced against the premise of a singular, authoritative truth, shame is contingent on either an exclusion from the conditional secret or a disregard of its lesson. It is "shameful" not to know the secret, and one can feel ashamed in the presence of the uninitiated. To be shameless, on the other hand, is to be indifferent to shame, and so to the authority that conditions what is and is not shameful. As Martinsen writes in her study, shame "lies on the boundary between self and other and is thus intimately linked to the question of identity" [Martinsen 2003: xiv]. An individual's identity, its subjection to an authoritative ideological narrative (the unveiling of the secret), is assured by and through the concordance of a multiplicity of subjects. One's subjectivity is never guaranteed but must instead be striven for and maintained within the borders of that same ideological authority. Overcoming the shameful, then, is the method for, and consequence of, the subjugation of the subject. As such, it represents the pathway to sincerity. "To thine own self be true is" simultaneously advising sincerity and cautioning against shame. This is why Polonius follows it with "Thou canst not then be false to any man." Sincerity is upheld through the avoidance of appearing shameful before others, thus damaging a sense of interior authenticity, by betraying the dictates of a singular ideological truth.

"The old powers of shame have been abolished," bemoans the narrator of J. M. Coetzee's politically critical novel, Diary of a Bad Year [Coetzee 2008: 39]. There is perhaps no truer testament to that lament than Trump's success. Yet Trump's shamelessness is more than just the catharsis of the old powers of shame, now permitted by the dawn of the post-truth age. As a political tactic, shamelessness is an effective means of promoting an alternative narrative that maintains the structure of the conditional secret, and so maintains the relation between authoritative power and individual subjection. If shame is contingent on the dynamic of power, sincerity and the traditional concept of a singular truth, then shamelessness emerges in the post-truth age as the best, maybe even only, assurance of an alternative authority precisely 
because of its antagonism to that very tradition. Against an outdated culture in which sincerity meant the avoidance of shame, shamelessness manifests as a surrogate for sincerity. Trump casts any claim to veracity as unverifiable, engendering the bewilderment of the post-truth and perpetuating a culture obsessed with sincerity and yearning for a meaning it can no longer find. He then puts forward his own alternative facts, which rely on the structure of conditional secrecy but that, by their shamelessness, offer their own new type of sincerity for people that have grown cynical to traditional sincerity. His shamelessness is thereby granted immunity from postmodern cynicism. And so, his alternative facts stand in for a now-obsolete singular truth. His power is legitimised because his narrative is shameless.

\section{III}

The kind of new sincerity Wallace represents, therefore, grows from the same socio-cultural conditions that gave rise to the type of political tactic that Trump successfully employed. Such is the basis of Colton's initial comparison. Yet Colton misperceives Trump's strategy of shamelessness, the way shamelessness is positioned as an alternative narrative to traditional power structures, allowing its practitioners to occupy a post-truth power vacuum. Wallace, on the other hand, wrestled throughout his writing life with the anachronism of sincerity as tied to a singular ideal of truth. His essays, interviews and fiction, including his 1996 magnum opus, Infinite Jest, were prompted by what he saw as the quintessential solipsism of the millennial American subject. Wallace's renown essay on television, "E Unibus Pluram," traces this solipsism back to the commercialised co-opting of the cynical and ironising tendencies of early American postmodern fiction and art. The cynicism of American metafiction of the 1960s may have been "socially useful" in exposing "a deeply hypocritical American self-image," the celebration of "the banal, the naïve, the sentimental and simplistic and conservative" at a time when television itself revealed "corporate ascendency, bureaucratic entrenchment, foreign adventurism, racial conflict, secret bombing [...] etc." [Wallace 1998: 65-66]. But by the late ' 80 s and early ' 90 s, the negatory power of irony was itself a fundamental component of television's cycle of viewership: everything from self-aware Pepsi commercials to icons of ridicule like Homer Simpson were intended to cultivate the viewing pleasure of isolated individuals by affirming them as superior to the norm, as in on the joke. This in turn engendered "a wider shift in U.S. perceptions of how art was supposed to work;" it transitioned from "a creative instantiation of real values" to "a creative rejection of bogus values" [Wallace 1998: 59]. The 
"postmodern aesthetic" paralleled "some deep and serious changes in how Americans chose to view concepts like authority, sincerity, and passion." Those concepts were "now 'out,' TV-wise." And this shift caused "great despair and stasis in U.S. culture," effectively laying the foundations for the rise of post-truth shamelessness as a political tactic [Wallace 1998: 59, 49].

A few years after "E Unibus Pluram," Wallace published Infinite Jest, which in many ways portrays through fiction the despair and stasis analysed by the essay. Set in an imagined future (corresponding to 2009), the novel envisages a culture in which sincere, ethical connections with others are treated with suspicion or outright dismissed. Most of the characters from Infinite Jest suffer from the solipsism laid out in "E Unibus Pluram." They are trapped in the isolated pursuit of pleasure to fill their spiritual and ethical emptiness, and the novel warns against the inherent dangers of that pursuit by centralising two related forms of pleasure dependency: an alcohol/drug addiction (which produces some of the novel's most harrowing scenes) and the titular Infinite Jest, a film so addictively entertaining that its viewers expire in a state of catatonic bliss. These central motifs are in turn united by Infinite Jest's overarching theme: the depression caused by an inability to overcome culturally embedded cynicism and forge meaningful relations outside of the self. The novel's near obsession over the difference between language as a means to knowledge and language as a means to communication is typical of this theme.

Central to the representation of this difference is Hal Incandenza, one of Wallace's protagonists and, as the emotionally detached intellectual of the three Incandenza brothers, a neotype of Ivan Karamazov. Hal's intelligence and mnemonic prowess, particularly his memorisation of the dictionary, are constantly flaunted throughout the novel. Yet they are just as constantly juxtaposed with his communicatory failures. From Hal's somewhat absurd appointment with a "professional conversationalist," to the suggestion that Hal's father made the lethal Entertainment as a desperate attempt to communicate with his son, to the final chronological scene of the book (also its opening chapter) in which Hal has been reduced to making only horrifying, animalistic noises, this physical incapacity to speak literalises Hal's symbolic isolation from others [Wallace 2012: 3-17, 28, 838-839]. And in one of Infinite Jest's important scenes, Hal is shown to be paradigmatic of "the theology of millennial America." Narratively admitting that his lack of "a bona fide intensity-of-interior-life-type emotion" means that "inside Hal there's pretty much nothing at all," it dawns upon Hal that the "one thing he feels to the limit" is that "he is lonely" [Wallace 2012: 694]. This brings him to 
the conclusion that his generation has entered into a "spiritual puberty where we snap to the fact that the great transcendent horror is loneliness, excluded engagement in the self" [Wallace 2012: 694]. Yet within the cultural milieu of Hal's America, languishing in the legacy of postmodernism, the only remedy left is "to fashion masks of ennui and jaded irony," trusting in "the weary cynicism that saves us from gooey sentiment [which] equals naïveté on this continent." Hal is thus trapped by "the queerly persistent U.S. myth that cynicism and naïveté are mutually exclusive." The emotional and ethical connections he needs to break from his solipsistic cage are impeded by the "hip cynical transcendence of sentiment" he must assume in order "to fit, be part-of, not be Alone" [Wallace 2012: 694]. Hal subsequently theorises that "the way he despises what it is he's really lonely for: this hideous internal self, incontinent of sentiment and need" is "[o]ne of the really American things" about him [Wallace 2012: 695].

It is the extension and exacerbation of the trap Hal finds himself caught in that, I argue, paved the way for the post-truth yearning for a new sincerity and the rise of shamelessness as a valid alternative narrative. However, in spite of the ethical (and hyperbolised physical) suffering it depicts, Infinite Jest is at the same time keenly aware of the danger of alternative narratives with an emboldened claim to veracity in the wake of the postmodern/poststructural deposition of traditional singular truth. On the one hand, it darkly satirises philosophical and political ideologies that seek either to return to anachronistic values and principles, such as the bombastic German Idealism espoused by the aptly named Coach Schtitt, or promote the kind of quasi-fascism advocated by fictionalised Quebecois separatists and their terrorist branch, the Wheelchair Assassins. On the other hand, institutional ideologies established to help the isolated and the desperate, especially the Alcoholics/Narcotics Anonymous centres that are prominent in the book, are treated with overt wariness and scepticism. ${ }^{7}$ The novel throughout maintains Hal's primordial cynicism towards both traditional concepts of truth and sincerity, and any suggested alternative.

Notable in this regard within the context of this essay is the President of ONAN, the Organisation of North American Nations evolved from the fictional merger of the U.S., Canada and Mexico. President Johnny Gentle, a former celebrity-turned-politician, was an outsider for the office but grew in popularity as the founder and leader of the "Clean U.S. Party," merging "ultra-right jin-

7 The overlap between AA/NA and institutional religion is treated in depth by several articles in [McGowan, Brick 2019]. 
goist hunt-the-deer-with-automatic-weapon types and far-left macrobiotic [...] ponytailed granola crunchers" [Wallace 2012: 382]. Despite drawing "mainstream media guffaws" to begin with, Gentle builds from the "disillusioned fringes" of "an increasingly [...] pissed off American electorate," sweeping to victory "in an angry reactionary voter spasm" [Wallace 2012: 382]. His other similarities to Donald Trump include support for "a new-era'd nation that looked out for Uno" [Wallace 2012: 383] and a commitment to finding "some cohesion-renewing Other" [Wallace 2012: 384] that the American public can blame for its woes. In this respect his environmentalism, far from being antithetical to Trump's real-life disregard of the climate crisis, is an extension of his unconcealed germaphobia, which is itself merely a hyperbole of the xenophobia that Wallace associated with extreme conservatives like Rush Limbaugh [Wallace 2012: 382]. And while the manipulation of shamelessness is not definitively identifiable as a way Gentle procured voter trust in his sincerity, Infinite Jest does associate the legacy of postmodern cynicism with the kind of conditions that allow for Trump/Gentle success. By his very departure from the norm, his willingness to transcend traditionally accepted boundaries of sincerity and decency, and his emphasis on image over substance, Gentle is able to occupy a power vacuum whilst retaining the narrative of conditional secrecy that anchors his political ascendency. Infinite Jest thereby cautions against both the dangers of a world mired in cynical isolation, addicted to self-gratification and lacking sincere ethical connection, and against the dangers of sincerity itself. Any new form of sincerity cannot overlook the socio-cultural shift of modernism-postmodernism without risking Gentle or the Wheelchair Assassins; this is what Colton's assessment of New Sincerity and Trump fails to account for. An impasse is established wherein the post-truth expression of sincerity must simultaneously account for a deep-seated socio-cultural cynicism towards the sincere.

This is the aporia of Wallace's New Sincerity, as Adam Kelly reads it. Kelly's article begins with the fundamental contradiction of narrative sincerity. A writer's primary ambition is to obtain a readership: writers write in the knowledge they will be read. A writer like Wallace, therefore, for whom sincerity was a central concern, must marry a desire for sincerity with an awareness of that desire. Wallace must both be sincere and seem so to his readers. ${ }^{8}$

8 This exact conundrum is the subject matter of "Pop Quiz 9," a subsection of Wallace's short story "Octet" which appears in the collection Brief Interview with Hideous Men. For a detailed analysis of the story, see [Williams 2015]. For the sake of brevity, and because Williams's excellent initial reading deteriorates into a befuddling attack on Wallace's supposed elitism, I have chosen not to engage with it here. 
Because his fiction interrogates the blurred lines between an authentic self and sincerity's "anticipatory logic," yet refuses to reject sincerity altogether, it requires "a rethinking of sincerity's rhetorical basis" [Kelly 2010: 135, 136].

Kelly achieves this by reading Wallace alongside Derrida's deconstruction of the metaphysics of presence. He aligns a poststructural critique of the phonocentrism of Western philosophy with traditional sincerity, in that both were attentive to "an obsession with univocal meaning, which still framed understanding even in a supposed age of irony" [Kelly 2010: 137]. With the profusion of exposure to advertising in an increasingly digital age, a key aspect of both "E Unibus Pluram" and Infinite Jest, it has become "impossible to separate in an absolute manner" genuine communication between speaker/author/broadcaster and listener/reader/viewer from narratives "that serve primarily to draw attention" to the former group [Kelly 2010: 137]. To attempt to do so "is to desire the recovery of a pure sincerity," a Wallacean dream that is reminiscent of "the lost wholeness of intention associated with speech and presence" in Derrida [Kelly 2010: 137]. More useful for both, argues Kelly, "would be to construct a logic that can account for [the] impurity and impossibility" of sincerity in a traditional sense, and this "logic" would "begin by recognizing the lack of any transcendent, absolute, Archimedean point from which to judge the authentic from the inauthentic, the sincere from the manipulative, truth from ideology" [Kelly 2010: 137-138]. Impatient with "rhetorical innocence and self-justificatory claims of detachment or transcendence," both Derrida and Wallace "develop a writing that relentlessly interrogates its own commitment" [Kelly 2010: 138]. Not only can such writing overcome the ideological absolutism of traditional sincerity, it also offers an alternative to a Ricoeur-like "hermeneutics of suspicion" that has dominated critical discourse since the dawn of modernism and is central to the prevalence of cynicism and irony in postmodern art and society. As Kelly reads it, the problem both Derrida and Wallace had with hermeneutic suspicion is its failure to account "for the persistence of the truly valuable in human life - traits such as love, trust, faith and responsibility" [Kelly 2010: 139].

Instead, therefore, of the totality of knowledge that comprises any discursive structure based in conditional secrecy, Wallace reformulates discourse within the scope of the Derridean gift: at once a conditional economy of exchange (giving in order to receive - the foundation of ideological authority) and "the incalculable, the unconditional, a relation to the other that goes beyond all form of cognition" [Kelly 2010: 139]. This is why, in order to approach traits such as love and responsibility without succumbing to "her- 
meneutical pitfalls," Wallace must work through the frame of paradox and aporia [Kelly 2010: 139]. Hence "the crucial importance of double binds" in his work: writing that both is and is not sincere, rehabilitation programs that work in spite of the patient's scepticism, the impossibility of reasoning one's way out of a mental illness [Kelly 2010: 139]. The "impossibility of knowledge" is "fundamental to the idea of gift," and so Wallace's newly sincere discourse "must take place in the aporia between the conditional and the unconditional" [Kelly 2010: 139-140]. The "unconditional secret" at its heart, unlike the maintained conditional secrecy of political shamelessness, must "resist power and knowledge, instead inducing weakness and epistemological humility" into narrative art [Kelly 2010: 143].

\section{IV}

An understanding of new sincerity in this sense allows for an approach to Dostoevsky's influence over Wallace that takes the dynamics of sincerity, shame and Levinas's theorisation of the ethical into account. As mentioned above, a conspicuous avenue into reading the literary relationship between Dostoevsky and Wallace is the latter's review of Joseph Frank's The Miraculous Years. Morphing into a contemplation on the differences between Dostoevsky's own "engagement with deep moral issues" and the "ironic distance from deep convictions or desperate questions" instilled in Wallace's contemporaries, the review methodically (if reductively) places Dostoevsky at the apotheosis of so-called "serious' literature," the type "aesthetically distanced" from the congenital scepticism of "our own art's culture" [Wallace 2014: 272]. However, Wallace's placement of Dostoevsky also suggests a correspondence between Dostoevsky and his own writing that overcomes this historical and cultural difference. If it were, as Wallace suggests, the "good old modernists" who "elevated aesthetics to the level of ethics - maybe even metaphysics," to such an extent that "Serious Novels after Joyce tend to be valued and studied mainly for their formal ingenuity," then Dostoevsky becomes representative of both sides of the divide [Wallace 2014: 271-272]. His treatment of "the stuff that's really important," such as "identity, moral value, death, will [...] reason, faith," align him with the single-entendre principles of traditional sincerity [Wallace 2014: 265]. Yet if, following Ricoeur, the dominance of the hermeneutics of suspicion was initiated by the proto-modernist "masters of suspicion," Marx, Freud and Nietzsche, then Dostoevsky's post-Siberian works can likewise be associated, historically at least, with the usurpation of single-entendre principles [Ricoeur 2008: 33, 35]. Notwithstanding the intertextual relations between 
Dostoevsky, Marx, Freud and Nietzsche, Joyce himself once claimed Dostoevsky "more than any other [...] created modern prose."

Meanwhile, Infinite Jest's active debt to Dostoevsky emboldens Dostoevsky's theoretical threshold position between "serious literature" and the suspicious-through-sceptical tendencies of modernism/postmodernism. Whilst on the one hand Wallace's review laments the thematically lightweight literature of millennial America when compared with Dostoevsky's own works, on the other it argues that Dostoevsky could and should remain a significant ethical precedent for his contemporaries, even if that significance has to work through the legacy of postmodern cynicism. This argument is actualised in Infinite Jest by Hal's brother, Mario. In the Incandenza/Karamazov structure of the work, Mario is a neotype of Alyosha Karamazov. ${ }^{10}$ And, like Alyosha, Mario is the ethical centre of Wallace's novel. Indeed, in one of Infinite Jest's most noteworthy ethical scenes, and the only that directly references The Brothers Karamazov, Mario's naivety and compassion for others breaks the cycle of spiritual dilapidation and ethical cynicism. During the narration of the backstory of a minor character who, after a long spiritual decline, ends up homeless and begging strangers merely for human contact, Mario is shown to be the one who acquiesces, beginning a "kind of heartwarming and faith-reaffirming series of circumstances" [Wallace 2012: 971] that leads to that character's eventual redemption. Mario's consent for human contact occurs only because he "had no one worldly or adult along with him" to advise him against it [Wallace 2012: 971]. In this way Wallace declares worldliness, equatable to Hal's world-weary cynicism, as the primary cause of millennial America's ethical infirmity. Mario's childlike humaneness is positioned as a potential antidote, "not that much unlike Alyosha [...] in the good old Brothers K." [Wallace 2012: 969].

Situating Dostoevsky on the threshold of traditional sincerity and the dispersal of that tradition, and subsequent rise of the need for a new theorisa-

9 Reported in [Power 1974: 58]. As far as I am aware, there is no single monograph devoted to an analysis of Freud, Marx, Nietzsche and Dostoevsky collectively. However, given the multiple studies that treat two or three of these writers together, one can presume that such an analysis would prove fruitful. Freud himself studied The Brothers Karamazov in the article "Dostoevsky and Parricide," whilst Nietzsche noted Dostoevsky's influence in Twilight of the Idols.

10 However, due to his physical deformities and uncertain parentage, Mario also shares characteristics with Smerdyakov. Yet, I would argue, this Karamazovian duality to Mario is typical of Wallacean new sincerity, which could not uncritically endorse such an ethical ideal but must instead treat it within a paradoxical framework, in the aporia between the conditional and the unconditional. 
tion of sincerity, is important in allowing for a twofold approach to shame in Dostoevsky, to treat shame as a stick with two ends. The relevance of what Martinsen calls Dostoevsky's "shame dynamics" to Wallace's new artistic sincerity should not be overlooked: the socio-cultural solipsism that Wallace critiques anticipated the post-truth conditions which gave rise to shamelessness as a political tactic. And while President Gentle may be a prescient forebear of President Trump, the latter has a true archetype in the shamelessness of Fyodor Karamazov [Martinsen 2003: xiii ff.]. As Martinsen writes, Fyodor "knows the most effective way to provoke those who uphold the status quo [...] is to speak or act inappropriately or shamelessly" [Martinsen 2003: 211]. This is the realisation that likewise founds Trump's political machinations. By provoking the status quo, Trump contributes to its repudiation and advocates his own narrative as its primary alternative.

Martinsen's approach is to layer an examination of Dostoevsky's liars, and the shame they cause themselves and others, over a theory of Dostoevsky's narrative workings. Her principal assertion is that Dostoevsky's most scandalous liars are, in varied ways, driven by an interior shame that forces them to abandon traditional notions of authenticity and sincerity. Liars such as General Ivolgin and Captain Lebyadkin tell stories about themselves to elevate their own sense of self-worth, in order to either belong amongst or feel superior to their interlocutors. It is in this way that shame lies on the boundary between self and other: self-identity is contingent on conformity to an externally mandated ideal that is affirmed by the evaluation of others. Tracing a variety of such post-Siberian characters to illustrate their skewed relation between self-identity and truth, Martinsen goes on to argue that Dostoevsky's own narrative engages in metaliterary play with these characters: their lying reflects back on his own fictitious composition. There is thus a binary function to the exposition of shame. In the first instance, it "models a path out of the enclosed self," advocating the freeing of "oneself from the prison-house of ego, where shame works as the chief jailer, and joining community" [Martinsen 2003: 219]. Shame works as a redemptive tool for the individual character, clearing the path for an authentic self to emerge from the egoism of falsehood and engage sincerely with others. In the second instance, shame reflects back upon both the witnesses to shame and scandal, and upon the readers themselves. This is key, claims Martinsen, to Dostoevsky's overarching narrative ethics. By "positioning readers as witnesses to exposed shame, Dostoevsky makes us experience our own post-lapsarian heritage, dramatizing his social, political and metaphysical message of human interconnection" [Martinsen 2003: xiv]. This hereby "reveals fiction's 
function not only to expose but possibly to save readers as he affords us ethical awareness and thus the impetus to change" [Martinsen 2003: xiv]. In both instances, shame demands reconciliation between the subject and a singular ideal of truth. It is based on the premise that the lies we tell ourselves are singularly unethical.

Fyodor Pavlovich's shamelessness, instead of serving as a departure from singular truth and sincerity, extends Dostoevsky's shame dynamics as Martinsen reads them. Fyodor follows the same route as Dostoevsky's other liars, creating embellished, occasionally absurd, narratives to aggregate his sense of self and better adhere to an ideological standard of propriety, virtue and respectability, which must be confirmed by others within his social circle. When others do not confirm Fyodor's self-image, the exposure of his insincerity causes an internal sensation of shame (feeling ashamed) and provokes the affective shame of witnesses. Yet while a character like General Ivolgin, for example, "responds in a more socially expected and acceptable manner, first by denying his plagiarism and then by fleeing," Fyodor "responds aggressively, shamelessly passing along his shame" [Martinsen 2003: 52].

The scene Martinsen gives most focus to in her study is related in Book 2 of The Brothers Karamazov, translated by Pevear and Volokhonsky as "An Inappropriate Gathering," in which Fyodor Pavlovich, his one-time cousin-in-law Miusov and his three sons visit the Elder Zosima's monastery, hoping to resolve an inheritance dispute between Fyodor and his son Dmitri. An essential component of this scene is the way it illustrates the particular mechanisms of Fyodor's shamelessness. In a sacred place, amongst the kind of company his illusory sense of self feels should be his social equivalents, Fyodor's aggressive shamelessness reaches its highest level. His inclination to lie, to be a "buffoon," is not just exposed by his interlocuters, it is anticipated by them. On the journey to the monastery, Miusov, whose heavy emphasis on propriety and respectability marks him out as the narrative antipode of Fyodor Pavlovich and thus serves to emphasise the latter's shamelessness, starkly warns Fyodor to "control yourself. If you start any buffoonery, I have no intention of being put on the same level with you here" [Dostoevsky 2004: 36-37]. Miusov's comment makes it clear that Fyodor's shameless acts are part of a long-standing personality trait. Fyodor later refers to himself as a "natural-born buffoon" [Dostoevsky 2004: 41], an exaggerated claim perhaps but one that nevertheless implies a repetitive history of falsehoods to compensate an inflated self-image, the exposure of those falsehoods and the resultant shame, which over time developed into his distinct style of shameless hostility. If, as Martinsen writes, shamelessness 
"betokens an indifference to norms of social interaction, an indifference that arises from a sense of exclusion," then it can be understood how Fyodor's shamelessness manifested as "an aggressive defence against shame or the anticipation of shame" [Martinsen 2003: 217-218]. Readers can concoct a sense of Fyodor's past, augmented by the novel's introductory comments that depict his impoverished upbringing and subsequent miserly habits [Dostoevsky 2004: 7], in which the repeated debunking of his lies led first to a sense of exclusion, followed by an anticipation of shame and ultimately to a continual pre-emptive shamelessness.

Moreover, Miusov's rebuke also exemplifies the function of Fyodor's buffoonery, a function that stems from the evolution of Fyodor's shamelessness. Fyodor's capacity to anticipate shame corresponds with an awareness of how others perceive him as socially inferior. Though constantly in conflict with his own narcissism, this awareness hinders him from ever following the exposure-to-redemption pathway laid out by General Ivolgin and others. Fyodor can never fully commit to his own lies, can never truly believe he will be accepted by his idealised social stratum. His shameless rhetoric, therefore, "betrays awareness of ways to overcome [his] isolation" [Martinsen 2003: 218]. He compensates for his inability to elevate his own social position by demoting, through an aggressive shamelessness, the social standing of those around him. He drags them down to his level. Miusov, who, as an "enlightened, metropolitan, cosmopolitan [...] lifelong European" [Dostoevsky 2004: 10] represents a strict adherence to the singular Enlightenment principles on which sincerity and shame are based, is accordingly the most affected by Fyodor's tactic. Even prior to Fyodor's more scandalous outbursts, Miusov admits to being "afraid to appear amongst decent people with him" [Dostoevsky 2004: 37]. It is a fear that, as Miusov knows in advance, his irritation with Fyodor will cause him to "start arguing ... lose my temper [and] demean myself and my ideas" [Dostoevsky 2004: 38]. Miusov shames himself in response to Fyodor's shamelessness, losing his patience and appearing "ridiculous" [Dostoevsky 2004: 42] by his participation in Fyodor's "unworthy farce" [Dostoevsky 2004: 43]. In this manner Fyodor achieves his distorted aim of social equivalence with Miusov and the others.

For Fyodor Pavlovich however, as the novel shows, this tactic only offers a temporary respite from his alienation. Central to Martinsen's study of Fyodor is her argument that shamelessness "not only perpetuates but also exacerbates" the sense of "exclusion it is intended to counter against" [Martinsen 2003: 218]. The struggle between Fyodor's inclination to elevate his own sense of self and debase those around him, read as "his conflicting 
desires to alienate and join his fellow men," means "he cannot engage in sincere dialogue" and thus finds himself "at the center of shame's paradox" [Martinsen 2003: 6]. Her argument is contingent upon a reading of the Elder Zosima as the spiritual and moral touchstone of the novel: the Elder's advice to Fyodor, which Martinsen perceives as critical to the ethics of shame in The Brothers Karamazov, is for him to unite his internal authenticity and external sincerity within the parameter of a singular ideal of truth. The core of his message is to tell Fyodor to

...not lie to yourself. A man who lies to himself and listens to his own lie comes to a point where he does not discern any truth either in himself or anywhere around him, and thus falls into disrespect towards himself and others. [...] A man who lies to himself is often the first to take offense. [...] And surely he knows that no one has offended him, and that he himself has invented the offense and told lies just for the beauty of it, [...] he knows all of that and still he is still the first to take offense, he likes feeling offended, it gives him great pleasure, and thus he reaches the point of real hostility... [Dostoevsky 2004: 44].

The remarkableness of this passage, for the purposes of the current article, is the strength of its resemblance to Trump's use of shamelessness as a political strategy. The faults Zosima diagnoses in Fyodor Pavlovich were all principal components of Trump's election campaign and presidential tenure: a seemingly pathological inability to discern fact from fiction, a lack of respect for self and others, a tendency to identify as the victim suggestive of a pleasure in taking offence, and a quickness to hostility are all marks of the political use of shamelessness on both sides of the spectrum in the post-truth era.

For Fyodor Karamazov, breaking from the cycle of deception and shamelessness is critical for his reintegration into a world still structured by singular principles, either religious or philosophical. Indeed, the salient tension of The Brothers Karamazov is the potentially eschatological consequences of the disintegration of those principles. For Martinsen, the ethical message of the novel arises in how Ivan Karamazov, teetering on the threshold between a community unified under singular ideals and the solipsism of amoral nihilism, is able to heed Zosima's advice even where his father failed [Martinsen 2003: 216]. Yet through the transition from Dostoevsky through modernism, postmodernism and eventually to the post-truth era that necessitates new understandings of sincerity, the power of traditional shame to eth- 
ically regenerate the falsified and the scandalous has weakened irreparably. Dostoevsky anticipates this weakening in the character of Smerdyakov in The Brothers Karamazov, but even more effectively in Demons through his portrayal of Stavrogin and Pytor Verkhovensky (as hinted at by Kokobobo's articles). Their collective shamelessness does not force their nihilist followers to confront their own relation to singular truth because those followers have already given that relation up. For them, as for the followers of Donald Trump who stormed the Capitol on January $6^{\text {th }}$, shamelessness and scandal already have as valid a claim on truth as anything that went before them.

$\mathrm{V}$

Rescuing sincerity from the anarchy of shamelessness, therefore, demands a reconsideration of its affiliation with single-entendre values and principles. New sincerity cannot, as Colton critiques, reiterate sincerity's traditional form, for doing so would give up any claim to novelty and so register only as an anachronism, easily dismissed in a post-truth world, a world of disputable facts, in which shamelessness offers the strongest claim to veracity of any and all alternatives precisely because of its elemental opposition to traditional sincerity. By way of concluding, I will suggest a reading of shame in Dostoevsky that accords with the ethical philosophy of Emmanuel Levinas, for whom Dostoevsky was a source of inspiration. Levinasian ethics argue for an illimitable responsibility for that which is absolutely Other, based not on ideological imperatives but on the primordial "accusative-ness" of subjectivity as subjected. For Levinas, the subject's originary state is passivity, summoned into being by the call of the Other: "the word $I$ means here I am [me voici], answering for everything and everyone" [Levinas 2016: 114]. In this sense, they resist the singular and totalising mandates of absolute religious or philosophical authorities, breaking the relation between authoritative power and individual subjection: responsibility is not based in conditional secrecy but is an inherent part of being, reanimated with every approach of that which is Other. By virtue of the unknowability of alterity, which breaches both the cognitive and ideological totality, Levinasian ethics accords with the aporetic necessity of Wallace's new sincerity. It offers an ethical basis for subjectivity that withstands the correlation of knowledge and power structuring Enlightenment ethical ideals, and is thus immune from the modernist hermeneutics of suspicion and subsequent cynicism of postmodernism. A Levinasian reading of shame in Dostoevsky therefore better accounts for Dostoevsky's ethical influence over Wallace, particularly with regards to how Levinasian responsibility and the aporia of new sincerity can 
both be traced back to authorial epistemological humility which constitutes the polyphonic novel structure.

Towards the end of the opening chapter of her study, whilst laying out the methods by which Dostoevsky employs shame as an ethical tool, Martinsen offers an extended elaboration of shame's psychosocial function:

A person possesses a coherent sense of self and the world only when his or her experience itself is coherent by virtue of predictably recurring elements (an entirely random, unpredictable flow of events cannot be intelligible). To the extent that shame introduces unexpected exposure, disrupted expectations, and the like, it renders experience, and thereby a sense of self and of the world, less coherent. Shamed persons, however inarticulately, are aware of this disruption and pained by it: they perceive, more or less clearly, that their sense of self - hence their identity —is at risk [Martinsen 2003: 16].

This is how shame works at the level of plot within Dostoevsky, and Martinsen extends her reading to account for Dostoevsky's own metafictional use of shame. Like a character's coherent sense of the world, a reader approaches a narrative searching for a sense of predictability in order to orient the reading experience. "Portrayed shame," therefore,

...disrupts readers' expectations and sense of personal inviolability.

Shame is always unexpected. [...] When Dostoevsky surprises his readers with shame, readers experience a similar disruption, disorientation, and self-consciousness. [...] Dostoevsky thus reveals our complicity in the status quo. He exposes our desire to keep the covers up [Martinsen 2003: 16].

The correlation between the way Martinsen here describes shame and the way Levinas theorises the approach of the Other which constitutes the ethical is conspicuous. In his first major work, Totality and Infinity, Levinas describes the very process of cognition as the orientation of the alterity of the world in relation to the subject. Termed "the identification of the same," Levinas describes the cognitive act as a "sojourn" in the sense that it is a temporary excursion beyond the self that returns to enrich the self. A world that should be "foreign and hostile" is instead, through cognition, "revealed precisely as preeminently the same [...]. In a world which is from the first other the I is nonetheless autochthonous." Attributing meaning to the world is thus theorised in terms of "find[ing] in the world a site and a home" [Levinas 1969: 37]. Levinas places emphasis on the prehensile etymology of comprehension. Cognition is a grasping, a taking possession of. 
In a sense everything is in the site, in the last analysis everything is at my disposal, even the stars, if I but reckon them, calculate the intermediaries or the means. [...] Everything is here, everything belongs to me; everything is caught up in advance with the primordial occupying of a site, everything is com-prehended [Levinas 1969: 37-38].

The very process of cognition, then, is that which establishes the predictably recurrent elements constituting a person's coherent sense of self and the world. Both Martinsen and Levinas describe this process in terms of possession. To know something is, in a sense, to own it: knowledge extends one's personal nexus of relation which ultimately leads back to the self. The manner of shame is to disrupt the process of meaning-making, bringing to light the fundamental imperialism of cognition through exposure to that which escapes coherence. And this is the same exact function of the Other in Levinasian ethics. That which is absolutely Other

...calls into question the exercise of the same. A calling into question of the same - which cannot occur within the egoist spontaneity of the same - is brought about by the other. We name this calling into question of my spontaneity by the presence of the Other ethics. The strangeness of the Other, his irreducibility to the I, to my thoughts and my possessions, is precisely accomplished as a calling into question of my spontaneity, as ethics [Levinas 1969: 43].

It is here that one can perhaps gesture towards an ethical capacity for shame not related to the restoration of absolute principles but based in the subject's primordial responsibility for others, thereby overcoming the posttruth disdain for such values that pre-empted the political manipulation of shamelessness. A key component of Totality and Infinity is the iteration of individual cognition within philosophical or ideological structures; following from the Cartesian bifurcation of mind and world, the totalising impulse of Reason is merely a manifestation of subjective comprehension. As such, writes Levinas, "the universal identity in which the heterogenous can be embraces has the ossature of a subject, of the first person. Universal thought is an 'I think" [Levinas 1969: 36]. ${ }^{11}$ It is for this reason that "the concept of totality [...] dominates Western philosophy" [Levinas 1969: 21].

11 Levinas accordingly takes Descartes's "Third Meditation" musings on the infinite, as that which cannot be comprehended but only theorised, as the starting point for his ethical treatise. 
The approach of the Other in Levinas, like shame in Martinsen, disrupts the self to reveal its complicity in a totalising (i.e., shameful) status quo. This approach instantiates the subject's primary responsibility for the Other by demanding the subject respond to the unknowable, to the in-com-prehensible. Moreover, by drawing on the concept of the Other's "call," teasing out the etymological root of responsibility, Levinas elaborates on how the ethical instant is from the beginning dialogic in nature. The irruption of totality is enacted by the voice of the Other. The voice that calls the subject into being, demanding a response that manifests as a responsibility "for everything and everyone" [Dostoevsky 2004: 320], reiterates that demand with every utterance through its refusal to be subsumed within the subject's totalising exercise. The Other's transcendence of our cognition is achieved through expression: manifestation " $\kappa \alpha \theta$ ' $\alpha$ $\tau$ o consists in being telling itself to us independently of every position we would have taken in its regard, expressing itself' [Levinas 1969: 65]. And though Levinas often terms the Other's transcendence of the totalising grasp of knowledge the "face," he makes it clear that the face in his philosophy is not the physical, cognisable features of another person's visage but the means by which another expresses itself outside of the boundaries of subjective cognition. The "face is a living presence; it is expression. $[\ldots]$ The face speaks. The manifestation of the face is already discourse. [...] To present oneself by signifying is to speak" [Levinas 1969: 66].

It is here, then, that a reassessment of Dostoevsky's use of shame to account for his influence over Wallace's new sincerity presents itself. Within the "plurality of independent and unmerged voices and consciousnesses" which constitutes Dostoevsky's "genuine polyphony" as theorised by Bakhtin, an ethical application for "shame" unburdened by an association with the universalising tendencies of traditional sincerity can be sourced [Bakhtin 2014: 6]. Levinas stresses in Totality and Infinity that a "multiplicity of sentients would be the very mode in which a becoming is possible - a becoming in which thought would not simply find again [...] a being subject to universal law, producing unity" [Levinas 1969: 60]. In this way he associates the singular ideals of Western philosophical totalisation with the authorial monologism that Dostoevskian polyphony, for Bakhtin, serves as a departure from. So-called monologic characters are portrayed by Bakhtin as "voiceless slaves," "merged in the unity of the event" of the novel to such an extent that they become "simple object[s] of the author's consciousness" [Bakhtin 2014: 6-7]. Authorial monologism thus corresponds with 
the first-person ossature of universal thought. ${ }^{12}$ This then sets the stage for a reading that draws a parallel between Dostoevsky's use of shame and the irruption of totality by the voice in Levinas's ethics. The ethical dynamic of polyphony substitutes itself for traditional shame by enacting the disruption of the "status quo," here conceived of as the suppression of directly signifying voices and consciousnesses.

And this polyphonic disruption is not then reoriented back towards universal premises precisely because it represents a renunciation of the kind of authorial authority such premises are founded upon. Via the creation of the polyphonic novel, Dostoevsky incorporated the dynamics of shame into the narrative act itself. His combination of the authorial word "alongside [...] the full and equally valid voices of other characters" is itself a recognition of the inherent shamefulness (totalising quality) of authorial creation [Bakhtin 2014: 7]. Such is the twofold nature of Dostoevsky's metafictional use of shame in his novels. On the one hand, the witnessing of shame exposes reader complicity in a shameful status quo at the socio-political level. This is the way Martinsen understands Dostoevsky's metafictional aim to inspire positive social changes. Yet on the other hand, Dostoevsky's polyphony exposes the "shame" of cognition at the epistemological level, an unavoidable shamefulness that nevertheless subdues the primordial responsibility for the Other inaugurating subjectivity. Narrative polyphony operates at both levels, encouraging social redemption within the ideals of a traditional form of sincerity, and enacting a Levinasian sense of the ethical by incorporating a responsibility for the voice of the other within the narrative structure.

In this respect both a sacred and secular message can be found in Zosima's tenet of responsibility for all, aligning with Dostoevsky's historical position on the threshold of traditional sincerity and the dispersal of that tradition. Zosima's own Orthodoxy advocates it as a moral injunction, mandated by a divine authority, leading to the discord between theoretical and "active" love related in "A Lady of Little Faith" [Dostoevsky 2004: 53-59]. Its importance to Levinas, however, arises through its articulation of dialogic ethics: the call of the Other necessitates a response which is the first responsibility of subjectivity. This second message transgresses the dispersal of traditional sincerity by presenting Dostoevsky's renunciation of authorial authority as an act of epistemological humility. Whilst Dostoev-

12 There is a growing tradition of scholars comparing and contrasting Bakhtinian dialogism with a Levinasian understanding of the ethical. Some of the more notable that I have come across in include: [Erdinast-Vulcan 2013; Gardiner 1996; Murray 2000; Nealon 1997; Patterson 1988]. 
sky's works can be said to represent "serious literature," they also provide an ethical blueprint for the hermeneutics of suspicion, and consequently for the post-truth world. The political manipulation of traditional sincerity may depend on the maintenance of conditional secrecy, yet Levinasian ethics are contingent precisely on an unconditional responsibility for the unknown and unknowable voice of the Other. It does not require an alternative narrative to anchor the subject through a relation of power and knowledge; it is based in an eschewal of both. This is the reimagined "sincerity" that is sought in Wallace's writings: Kelly too notes that the New Sincerity movement "depends upon its becoming dialogic in character" [Kelly 2010: 141]. New sincerity is not therefore postulated on a truth "to thine own self" but instead requires a conscious commitment, in life and in art, to a humility before the cognitive aporia initiated by the voice of the Other. In a significant scene from Infinite Jest relating to the novel's ethical outlook, a character with both the power and a just cause to punish one of the protagonists instead strives not only to forgive that protagonist, but to actively seek his forgiveness for the resentment and hatred the character has harboured. As part of his AA recovery (which surrogates for his ethical redemption), the character must "put out my own hand and say that I'm sorry and ask that man's forgiveness for my own failure to forgive. This is the only way I'll be able to forgive him" [Wallace 2012: 963]. Despite his persistent belief that "that son of a bitch is evil and deserves to be removed from the community," the character nevertheless resolves

...to walk in there and extend my hand and tell him I've wished him ill and blamed him and ask for forgiveness [...]. Whether he forgives or not is not the issue. It's my own side of the street I need to clean [Wallace 2012: 963].

The character admits that he has not yet found the strength to forgive the protagonist, but the scene closes with him "wish[ing] to emphasize yet" [Wallace 2012: 964]. The new sincerity that Infinite Jest prescribes for postmodern cynicism, and that could be applied through its development to posttruth shamelessness, cannot be theorised as complete, or even achievable, but must instead be always already in need of renewal. Dialogic ethics are as active and as unconsummated as dialogue itself. Only then can they overcome the disparagement of totality that defines postmodern cynicism without retreating to a solipsist cage. Dostoevsky's legacy for Wallace was his narrative articulation of an ethics that relinquished its basis in universalising 
absolutes but retained a dialogic sense of community. This new sincerity accepts the inherent "shame" of epistemic coherence in order to combat the potential violence of post-truth shamelessness.

\section{REFERENCES}

Akker, Gibbons, Vermeulen 2017 - Akker, Robin van den, Alison Gibbons, and Timotheus Vermeulen, eds. Metamodernism: Historicity, Affect, and Depth after Postmodernism. London: Roman and Littlefield, 2017.

Alphen, Bal, Smith 2008 - Alphen, Ernst van, Mieke Bal, and Carel Smith, eds. The Rhetoric of Sincerity. Stanford: Stanford University Press, 2008.

Bakhtin 2014 - Bakhtin, Mikhail. Problems of Dostoevsky's Poetics. Edited and translated by Caryl Emerson. Minneapolis: University of Minnesota Press, 2014.

Coetzee 2008 - Coetzee, J. M. Diary of a Bad Year. London: Vintage, 2008.

Colton 2016 - Colton, Aaron. "Donald Trump and the 'New Sincerity' Artists Have More in Common Than Either Would Like to Admit." Paste Magazine, August 9, 2016. https:// www.pastemagazine.com/politics/donald-trump-and-the-new-sincerity-artists-have-mo/.

Dostoevsky 2004 - Dostoevsky, Fyodor M. The Brothers Karamazov. Translated by Richard Pevear and Larissa Volokhonsky. London: Vintage Books, 2004.

Erdinast-Vulcan 2013 - Erdinast-Vulcan, Daphna. Between Philosophy and Literature: Bakhtin and the Question of the Subject. Stanford: Stanford University Press, 2013.

Ferguson 1997 - Ferguson, Robert A. The American Enlightenment, 1750-1820. Cambridge, MA: Harvard University Press, 1997.

Gardiner 1997 - Gardiner, Michael. "Alterity and Ethics: A Dialogical Perspective." Theory, Culture and Society 13, no. 2 (1996): 121-143.

Jacobs 2007 — Jacobs, Timothy. "The Brothers Incandenza: Translating Ideology in Fyodor Dostoevsky's The Brothers Karamazov and David Foster Wallace's Infinite Jest." Texas Studies in Literature and Language 49, no. 3 (2007): 265-292.

Kelly 2010 - Kelly, Adam. "David Foster Wallace and the New Sincerity in American Fiction." In Consider David Foster Wallace: Critical Essays, edited by David Hering, 131-146. Los Angeles: Sideshow Media Group, 2010.

Kokobobo 2021 - Kokobobo, Ani. "Dostoevsky Warned of the Strain of Nihilism that Infects Donald Trump and His Movement." The Conversation. January 13, 2021. https:// theconversation.com/dostoevsky-warned-of-the-strain-of-nihilism-that-infects-donaldtrump-and-his-movement-152807.

Kokobobo 2016 - Kokobobo, Ani. "How Dostoevsky Predicted Trump's America." The Conversation. August 23, 2016. https://theconversation.com/ how-dostoevsky-predicted-trumps-america-63799.

Levinas 1969 - Levinas, Emmanuel. Totality and Infinity: An Essay on Exteriority. Translated by Alphonso Lingis. Pittsburgh, PA: Duquesne University Press, 1969.

Levinas 2016 - Levinas, Emmanuel. Otherwise than Being, or Beyond Essence. Translated by Alphonso Lingis. Pittsburgh, PA: Duquesne University Press, 2016. 
McGowan, Brick 2019 - McGowan, Michael, and Martin Brick, eds. David Foster Wallace and Religion: Essays on Faith and Fiction. New York: Bloomsbury Academic, 2019.

McIntyre 2018 - McIntyre, Lee. Post-Truth. Cambridge: MIT Press, 2018.

Martinsen 2003 — Martinsen, Deborah A. Surprised by Shame: Dostoevsky's Liars and Narrative Exposure. Columbus: Ohio State University Press, 2003.

Murray 2000 - Murray, Jeffrey W. "Bakhtinian Answerability and Levinasian Responsibility: Forging a Fuller Dialogical Communicative Ethics." Southern Journal of Communication 65, no. 2-3 (Winter/Spring 2000): 133-150.

Nealon 1988 - Nealon, Jeffrey T. "The Ethics of Dialogue: Bakhtin and Levinas." College English 59, no. 2 (February 1997): 129-148.

Patterson 1988 - Patterson, David. "Bakhtin and Levinas: Signification, Responsibility, Spirit." In Literature and Spirit: Essays on Bakhtin and His Contemporaries, 98-127. Kentucky: University Press of Kentucky, 1988.

Power 1974 - Power, Arthur. Conversations with James Joyce. Edited by Clive Hart. London: Millington, 1974.

Ricoeur 2008 - Ricoeur, Paul. Freud and Philosophy: An Essay on Interpretation. Translated by Denis Savage. Delhi: Motilal Banarsidass, 2008.

Robbins 1999 - Robbins, Jill. Altered Reading: Levinas and Literature. Chicago: University of Chicago Press, 1999.

Schaefer 2021 - Schaefer, Todd M. Presidential Power Meets the Art of the Deal: Applying Neustadt to the Trump Presidency. London: Palgrave Macmillan, 2021.

Trilling 1980 — Trilling, Lionel. Sincerity and Authenticity. London: Harcourt Brace Jovanovich, 1980.

Turner 2015 - Turner, Luke. "Metamodernism: A Brief Introduction." Notes on Metamodernism. January 12, 2015. http://www.metamodernism.com/2015/01/12/ metamodernism-a-brief-introduction.

Wallace 1998 - Wallace, David Foster. "E Unibus Pluram: Television and U.S. Fiction.” In A Supposedly Fun Thing I'll Never Do Again: Essays and Arguments, 21-82. Boston: Back Bay Books, 1998.

Wallace 2012 - Wallace, David Foster. Infinite Jest. London: Abacus, 2012.

Wallace 2014 - Wallace, David Foster. "Joseph Frank's Dostoevsky.” In Consider the Lobster, and Other Essays, 255-274. London: Abacus, 2014.

Williams 2015 - Williams, Iain. "(New) Sincerity in David Foster Wallace's 'Octet."' Critique: Studies in Contemporary Fiction 56, no. 3 (2015): 299-314. 